\title{
Delapril Hydrochloride
}

National Cancer Institute

\section{Source}

National Cancer Institute. Delapril Hydrochloride. NCI Thesaurus. Code C72734.

The hydrochloride salt of delapril, a lipophilic, non-sulfhydryl angiotensin-converting enzyme (ACE) inhibitor with antihypertensive activity. As a prodrug, delapril is converted to two active metabolites, delapril diacid and 5-hydroxy delapril diacid, which competitively bind to and inhibit ACE, thereby blocking the conversion of angiotensin I to angiotensin II. This prevents the potent vasoconstrictive actions of angiotensin II and results in vasodilation. Delapril also decreases angiotensin II-induced aldosterone secretion by the adrenal cortex, which leads to an increase in sodium excretion and subsequently increases water outflow. 